University of Nebraska - Lincoln

DigitalCommons@University of Nebraska - Lincoln

USDA National Wildlife Research Center - Staff Publications
U.S. Department of Agriculture: Animal and Plant Health Inspection Service

2014

\title{
Effects of spatiotemporal resource heterogeneity on home range size of American beaver
}

L. F. McClintic

Mississippi State University, Imcclin1@hotmail.com

J. D. Taylor II

USDA/APHIS/WS National Wildlife Research Center, jimmy.d.taylor@usda.gov

J. C. Jones

Mississippi State University

R. D. Singleton

United States Department of Agriculture

G. Wang

Mississippi State University

Follow this and additional works at: https://digitalcommons.unl.edu/icwdm_usdanwrc

Part of the Life Sciences Commons

McClintic, L. F.; Taylor, J. D. II; Jones, J. C.; Singleton, R. D.; and Wang, G., "Effects of spatiotemporal resource heterogeneity on home range size of American beaver" (2014). USDA National Wildlife Research Center - Staff Publications. 1519.

https://digitalcommons.unl.edu/icwdm_usdanwrc/1519

This Article is brought to you for free and open access by the U.S. Department of Agriculture: Animal and Plant Health Inspection Service at DigitalCommons@University of Nebraska - Lincoln. It has been accepted for inclusion in USDA National Wildlife Research Center - Staff Publications by an authorized administrator of DigitalCommons@University of Nebraska - Lincoln. 


\title{
Effects of spatiotemporal resource heterogeneity on home range size of American beaver
}

\author{
L. F. McClintic ${ }^{1}$, J. D. Taylor², J. C. Jones ${ }^{1}$, R. D. Singleton² \& G. Wang ${ }^{1}$ \\ 1 Department of Wildlife, Fisheries and Aquaculture, Mississippi State University, Mississippi State, MS, USA \\ 2 United States Department of Agriculture, Animal and Plant Health Inspection Service, Wildlife Services, National Wildlife Research Center, \\ Corvallis, OR, USA
}

\begin{abstract}
Keywords
Castor canadensis; central place forager; normalized difference vegetation index

(NDVI); resource distribution; space use.
\end{abstract}

\author{
Correspondence \\ Lance F. McClintic, Department of Wildlife, \\ Fisheries and Aquaculture, Mail Stop 9690, \\ Mississippi State University, Mississippi \\ State, MS 39762, USA. \\ Email: Imcclin1@hotmail.com
}

Editor: Jane Waterman

Received 20 December 2012; revised 24

January 2014; accepted 30 January 2014

doi:10.1111/jzo.12128

\begin{abstract}
Home range size of terrestrial animals may be influenced by spatiotemporal dynamics of resources. However, little is known regarding the effects of spatiotemporal resource availability on semi-aquatic central place foragers such as the American beaver Castor canadensis. From January 2011 to April 2012, 26 beavers at 11 wetlands at Redstone Arsenal in north-central Alabama, USA, were captured and radio-tracked using radio telemetry. The objectives of this study were to test the predictions of three hypotheses: (1) the resource dispersion hypothesis: more spatially dispersed resources throughout a landscape increase home range sizes; (2) the temporal resource variability hypothesis: more temporally variable resources result in decreases in home range sizes; (3) the habitat productivity hypothesis: increases in habitat productivity lead to decreases in home range sizes. Twenty-three of 26 radio-tagged beavers had well-bounded home ranges, and their home range sizes were positively related to the diversity of land cover within home ranges as predicted by the resource dispersion hypothesis. Furthermore, home range sizes of 26 beavers, including three seasonally dispersing beavers, decreased with increasing seasonal variability of within-home-range normalized difference vegetation index (NDVI), supporting the prediction of the resource heterogeneity hypothesis. Home range sizes of American beavers increased with increasing total NDVI and proportions of woody plant cover within home ranges probably to avoid overexploitation of woody plants. Our results suggest that the combination of resource quantity, spatial distribution and seasonal variation of resources influences movements and home ranges of central place foragers.
\end{abstract}

\section{Introduction}

A reoccurring theme in animal ecology is the influence of resource abundance and distribution on animal movements and space use (Mueller \& Fagan, 2008; Owen-Smith, Fryxell $\&$ Merrill, 2010). Multiple factors contribute to variation in home range size. Early studies of these factors focused on energy-related metrics: body size, metabolic requirements and habitat productivity (McNab, 1963). For instance, increased habitat productivity would lead to a decrease in animal home range size (McNab, 1963). However, spatial distribution and configuration of resources may also play an important role in shaping movement patterns and space use of animals (Mueller \& Fagan, 2008; Di Stefano et al., 2011).

Spatial distribution of resource availability has been shown to affect animal movements and home range sizes in terrestrial birds and carnivores (Johnson et al., 2002; Marable et al., 2012). The resource dispersion hypothesis states that as resources become more spatially dispersed (e.g. more spatially patchy distribution of resources), movements and home range size of animals will also increase (Johnson et al., 2002). For instance, habitat fragmentation increased movement distances and home range sizes of eastern wild turkeys, Meleagris gallapovo silvestris (Marable et al., 2012). Also, African lions, Panthera leo, may increase home range size partially due to increased dispersion of watering holes (Loveridge et al., 2009). However, it is uncertain whether herbivorous mammals, including semi-aquatic beavers (Castor spp.), may increase movements when habitat becomes fragmented.

Though much research has evaluated the effects of spatial distributions of resources on habitat use and home range size of animals, few studies have empirically investigated 
relationships between temporal variability of resource availability, such as seasonal variation in food abundance and home range sizes (Mueller \& Fagan, 2008; van Beest et al., 2011). Temporal pulses in quality of food resources can increase body mass in herbivores (Searle, Hobbs \& Jaronski, 2010). Animals may alter seasonal diets to take advantage of seasonal variations in food resource abundances to meet nutritional requirements. Consequently, more seasonally variable resources may provide animals with a sufficient amount of food within a smaller home range (Owen-Smith et al., 2010). Therefore, we hypothesize that temporal variation in food resource availability provides herbivores with different nutritional benefits during different seasons and subsequently reduces movement distances and home range sizes (i.e. the temporal resource variability hypothesis).

Animal foraging modes may affect movement patterns (Buchmann et al., 2012). For example, central place foragers often restrict their food acquisitions within a short distance from the central places of their home ranges (Fryxell, 1992; Campbell et al., 2013). American beavers, Castor canadensis (hereafter beaver) and Eurasian beavers, Castor fiber, are central place foragers with relatively bounded home ranges (Baker \& Hill, 2003; Haarberg \& Rosell, 2006; Raffel et al., 2009). Although the spatial distribution of resources influences habitat selection by beavers (Fryxell, 1992; John, Baker \& Kostkan, 2010), beavers may respond to spatiotemporal resource heterogeneity differently from terrestrial, patrolling or mobile foragers that can move throughout landscapes more freely than central place foragers (Buchmann et al., 2012; Campbell et al., 2013). Intensive food consumption in proximity of dens or central places by American beavers may deplete food resources surrounding the dens, particularly in less productive habitat (Johnston \& Naiman, 1990); consequently, beavers may enlarge home ranges to augment total food resource abundance to avoid overexploitation of food resources.

This study further expanded the hypothesis regarding the effects of resource heterogeneity to include a temporal dimension of resource heterogeneity. The current study aims to test the predictions of the following three hypotheses concerning intraspecific variation in beaver home range sizes. First, the resource dispersion hypothesis predicts that home range sizes of American beavers would increase with increasing land cover diversity index within home ranges. Greater land cover diversity within home ranges indicates greater patchiness, and thus, greater levels of habitat fragmentation. Second, the temporal resource variability hypothesis predicts that home range sizes of beavers would be smaller with more temporal variability in resource availability throughout the year. Last, the habitat productivity hypothesis predicts that home range sizes of beavers would be smaller in more productive habitats but larger in less productive habitats. Alternatively, American beavers would increase home range sizes to include more woody plants or green plant biomass to avoid overexploitation of resources within home ranges. Beaver home range sizes may be positively related to proportions of woody plant covers or total green plant biomass within home ranges.

\section{Methods}

\section{Study area}

Our study was conducted at Redstone Arsenal, a 15 342-ha US Department of Defense military installation located in Madison County, Alabama, USA (34⒊ $\left.\mathrm{N}, 86^{\circ} 39^{\prime} \mathrm{W}\right)$. Redstone Arsenal is bordered by the cities of Huntsville to the north and east and Madison to the west, with the Tennessee River as the southern boundary. Topography is relatively flat but very diverse, with elevation ranging from 165 to $365 \mathrm{~m}$. Landscape is composed of agricultural fields, military test ranges, bottomland hardwood forests, upland conifer forests, mixed forests and various water bodies, including many seasonal swamps and marshes that become inundated with water during the rainy season. Surface areas of water bodies ranged from 5.68 to 63.74 ha. Average monthly temperatures ranged from $8^{\circ} \mathrm{C}$ in December 2012 to $28^{\circ} \mathrm{C}$ in July 2011, with an annual mean throughout this study of $18^{\circ} \mathrm{C}$. Total precipitation from May 2011 to April 2012 was $125.5 \mathrm{~cm}$ and monthly precipitation varied from $3.4 \mathrm{~cm}$ in October to $19.8 \mathrm{~cm}$ in January (Huntsville-Decatur International Airport weather station, the National Oceanic and Atmospheric Administration station ID: 014064; approximately $14 \mathrm{~km}$ from study sites).

Beavers were captured from 11 wetlands located in the southern half of Redstone Arsenal. Beavers are widely distributed in the wetlands of southeastern US (Baker \& Hill, 2003) and no evidence suggests that beavers in Redstone Arsenal were reintroduced. The 11 wetlands varied in size, shape and wetland type (Supporting Information Table S1) and were initially selected due to presence of beaver activity. Distances between selected wetlands ranged from 278 to $9806 \mathrm{~m}$ and averaged $4942 \mathrm{~m}$ [standard deviation $(\mathrm{SD}=$ $2420 \mathrm{~m}]$.

\section{Capture, radio tagging and radio telemetry}

During January to May 2011, 50 beavers were live captured using Hancock live traps, which weigh $15 \mathrm{~kg}$ with a dimension of $71 \times 91 \times 10 \mathrm{~cm}$ (Hancock Trap Company, Custer, SD, USA). Hancock traps were placed next to beaver dams, scent mounds and movement corridors in each of the 11 wetlands. Commercial castor-based or food-based lures were placed in traps to attract beavers and increase trapping success. Traps with lures were activated daily before 15:00 $\mathrm{h}$ and checked the following morning by 09:00 h.

Captured beavers were weighed in traps using a hanging scale (Moultrie Feeders, Alabaster, AL, USA) to the nearest $0.1 \mathrm{~kg}$. Individual beaver body mass was estimated with difference in weight between a trap with and without a captured beaver. Captured beavers were classified into four age classes according to body mass: $<6.8 \mathrm{~kg}$ as 0 - to 12 -month-old kits; $6.8-10.8 \mathrm{~kg}$ as 13 - to 24 -month-old yearlings; $10.9-16.0 \mathrm{~kg}$ as 25 - to 36 -month-old subadults; and $>16 \mathrm{~kg}$ as $\geq 37$-month-old adults, respectively (Breck, Wilson \& Andersen, 2001; McNew Jr \& Woolf, 2005). Gender of captured beavers was not collected in the field. 
Beavers weighing $>6.8 \mathrm{~kg}$ were anesthetized with an intramuscular injection of ketamine hydrochloride $\left(10 \mathrm{mg} \mathrm{kg}^{-1}\right)$ and xylazine hydrochloride $\left(1 \mathrm{mg} \mathrm{kg}^{-1}\right)$ to aid in handling of live beavers (Arjo et al., 2008; Bloomquist \& Nielsen, 2010). While sedated, beavers were wrapped in a blanket to prevent hypothermia due to cold weather and the lack of muscle activity. ATS Model 3530 radio transmitters [Advanced Telemetry Systems (ATS), Isanti, MN, USA] were attached to 50 beavers using tail-mounting methods developed by Rothmeyer, McKinstry \& Anderson (2002) and modified by Arjo et al. (2008). Transmitters weighed $<0.05 \%$ of the beaver's body mass and had a battery life of 647 days. However, 24 beavers lost radio transmitters due to either failures or drop-offs of radio transmitters. Twenty-six radio-tracked beavers were monitored throughout the study.

After secure transmitter attachment, a passive integrated transponder $(125 \mathrm{kHz}$, Avid Identification Systems, Inc., Norco, CA, USA) was inserted subcutaneously between the scapulae using a single-use disposable syringe for permanent identification (ID) of beavers (Bond et al., 2001; Arjo, Huenefeld \& Nolte, 2007). Hair samples and tail tissue biopsy ( $3 \mathrm{~mm}$ ) were collected for future DNA analysis on all captured beavers. Radio-tagged beavers were released at the location of capture once fully recovered (i.e. alert and mobile). Sedation and handling time ranged from 30 to 60 minutes for each beaver. Trapping and handling of beavers was approved by the Institutional Animal Care and Use Committee of the US Department of Agriculture National Wildlife Research Center (Protocol \#: QA-1626).

Radio-tagged beavers were monitored $\geq 2$ times per week from May 2011 to July 2011 and biweekly from August 2011 to April 2012 using radio telemetry (White \& Garrott, 1990). Radio-tagged beavers were located throughout a 12-hour period (18:00-06:00 h) with an ATS 3-element hand-held Yagi antenna, an R-1000 receiver (Communications Specialist Inc., Orange, CA, USA), and a look-through compass (Model KB-20/ 360R, Suunto, Vantaa, Finland). Wetland order and time of night for tracking each radio-tagged beaver were varied across all occasions to avoid biased temporal distribution of relocations. Universal Transverse Mercator (UTM) coordinates of beaver locations were estimated using triangulation methods (Cochran \& Lord Jr, 1963) using the program Locate III (Tatamagouche, Nova Scotia, Canada) (Nams, 2006). At least three azimuths per animal with an overall separation of $60-120^{\circ}$ were recorded in $\leq 15$ minutes and adjusted for $3^{\circ}$ declination. UTM coordinates of observers' positions were obtained from a handheld Global Positioning System (GPS) unit (Model: GPSMap 76, Garmin Ltd, Olathe, KS, USA) with an accuracy of $\leq 3 \mathrm{~m}$.

\section{Home range estimation}

Fixed kernel smoothing methods with a least squared cross validation smoothing parameter in the Geospatial Modelling Environment (http://www.spatialecology.com/gme) of ArcMap10 (ESRI, Redlands, CA, USA) were used to estimate annual 95\% kernel home range sizes (ha) (Worton, 1989). All beavers $(n=26)$ used for analysis had $\geq 23$ location estimates with $95 \%$ error ellipse $<0.5$ ha to estimate beaver home ranges. Additionally, wet and dry season core use areas (50\% kernel smoothing home ranges) were estimated with all location estimates for each beaver, respectively. The distance $(\mathrm{m})$ between seasonal home range centroids was measured for each beaver in ArcMap10 to determine if beavers shifted their seasonal core use areas. If within-home-range resource availability varies seasonally in a predictable way, animals would not shift home ranges between seasons (Owen-Smith et al., 2010). Dry season was from April to August and wet season was from September to March, with seasonal precipitation of $37.95 \mathrm{~cm}$ and $87.60 \mathrm{~cm}$, respectively. The 11 wetlands were generally elliptical and not confined to linear active stream channels; thus, kernel smoothing methods for home range estimation were appropriate for beavers at the study site (Downs \& Horner, 2008; Bloomquist, Nielsen \& Shew, 2012).

\section{Land cover and diversity}

The National Land Cover Classification Database 2006 (http://www.mrlc.gov/nlcd2006.php) was used to derive a land cover and land use map at the 30-m resolution for the study area (Fry et al., 2011). The original four levels of developed class (class 21-24) were combined into one class (i.e. developed area). The resulting land cover types included water, developed area, deciduous forest, evergreen forest, mixed forest, shrubland, grassland, cropland and wetland. According to Fry et al. (2011), water and wetland are separate land cover types. Water is defined by areas of open water with $<25 \%$ vegetative cover or soil, whereas wetland, in this case woody wetland cover, is an area where forest or shrubland vegetation makes up $>20 \%$ of vegetative cover and soil or substrate is periodically saturated or covered with water (Fry et al., 2011). Landscape diversity within beaver home ranges using the Shannon diversity index was computed with the formula:

$$
S I=\sum_{i=1}^{n=9}-p_{i} \ln p_{i},
$$

where $p_{i}$ is the proportion of the ith land cover type (Tramer, 1969). Greater Shannon's diversity index values correspond to more vegetation patches within beaver home ranges.

\section{Normalized difference vegetation index (NDVI) within home range}

Normalized difference vegetation index (NDVI) was used to measure vegetation greenness as an index of plant standing biomass (Pettorelli, 2005). Cloud-free Landsat Thematic Mapper (TM) 5 imagery acquired on 14 February 2011, 3 April 2011, 5 May 2011, 6 June 2011, 25 August 2011 and 10 September 2011, respectively was obtained from the US Geological Survey Earth Resources Observation and Science Center remote sensing data archives (http://glovis.usgs.gov/). The Landsat TM 5 red light band with a wavelength of $0.63-0.69 \mu \mathrm{m}$ and near infrared (NIR) band with a wavelength of $0.76-0.90 \mu \mathrm{m}$ were used to compute NDVI for 
each cell $(30 \times 30 \mathrm{~m})$ with the formula: $\mathrm{NDVI}=(\mathrm{NIR}-\mathrm{red}) /$ (red + NIR) (Rouse et al., 1974; Lauer, Morain \& Salomonson, 1997). The raster calculator tool from the spatial analyst toolbox in ArcMap10 was used to compute NDVI of the study area for February, April, May, June, August and September. The program IDRISI Taiga 15.0 (Clark Labs, Worcester, MA, USA) was used to calculate mean total NDVI, mean cell-wise NDVI and coefficient of variation (CV) in mean cell-wise NDVI within 95\% fixed kernel home range over the 6 months for each radio-tagged beaver. $\mathrm{CV}$ in mean cell-wise NDVI within home ranges (hereafter, temporal CV in NDVI) was used to measure seasonal or temporal variability in food availability within beaver home ranges.

\section{Statistical analysis}

Pair-wise Pearson's correlation $r$ of Shannon's diversity index, temporal CV of NDVI, total NDVI, mean NDVI and body mass was computed to test for multicolinearity between pairs of predictor variables before regression analysis of beaver home range sizes. Mean NDVI was correlated with temporal CV in NDVI $(r=-0.70, P<0.01)$ and thus was excluded from regression because of interest in the effects of temporal heterogeneity of resources on beaver movements. Preliminary analysis also showed that body mass had no significant effect on home range size, so it was excluded in subsequent analysis. Other studies have also suggested that beaver home range sizes were not related to age and body mass (Bloomquist et al., 2012). Natural log transformation was used to normalize home range sizes and to linearize relationships between raw home range and predictor variables (Di Stefano et al., 2011; Bloomquist et al., 2012).

Eight linear models were built to determine relationships between log-transformed home range size and three predictor variables: Shannon diversity index, temporal CV of NDVI and total NDVI. Interaction terms were not included because of relatively small sample size $(n=26)$. Regression was conducted using linear mixed models with wetland ID as a random factor to account for interdependence between beavers of the same wetland, using the procedure MIXED of SAS (version 9.2, SAS Institute Inc., Cary, NC, USA). Model selection was conducted using an information-theoretic approach with Akaike information criterion corrected for small sample size (AICc; Burnham \& Anderson, 2002). The best approximating model among candidate models had lowest AICc value or highest Akaike weight (Burnham \& Anderson, 2002). Aikaie weight is a weight of evidence supporting a model. $\triangle \mathrm{AICc}$ of a model was calculated as the difference in AICc between the model and best approximating model. A model with $\triangle \mathrm{AICc}<2.0$ was a competing model with the best approximating model. If a predictor was included in the best approximating model or a competing model, then it was concluded that the predictor significantly affected beaver home range sizes. To test whether beaver home range sizes were related to the proportion of woody plant cover, log-transformed home range sizes were regressed on proportions of total woody plant covers (deciduous forest, mixed forest and shrubland) within home ranges, using mixed
Table 1 Model selection of eight candidate models for 23 radio-tracked American beavers Castor canadensis, excluding seasonally dispersing beavers, in northern Alabama, USA, 2011-2012

\begin{tabular}{lccc}
\hline Models & & & Akaike \\
Total NDVI & AIC $_{c}$ & $\Delta \mathrm{AlC}_{c}$ & weight \\
Total NDVI + Temporal CV + & -50.3 & 0.0 & 0.642 \\
$\quad$ Shannon's index & -48.0 & 2.3 & 0.203 \\
Total NDVI & & & \\
Total NDVI + Temporal CV & -47.1 & 3.2 & 0.130 \\
Temporal CV & -43.8 & 6.5 & 0.025 \\
Temporal CV + Shannon's index & 18.9 & 69.2 & 0.000 \\
Shannon's index & 19.1 & 69.4 & 0.000 \\
Null & 22.9 & 73.2 & 0.000 \\
\hline
\end{tabular}

${ }^{\text {T} T o t a l ~ N D V I ~=~ T o t a l ~ n o r m a l i z e d ~ d i f f e r e n c e ~ v e g e t a t i o n ~ i n d e x ~ w i t h i n ~ h o m e ~}$ range.

bShannon's index = Shannon's diversity index of land cover types.

'Temporal CV = Coefficient of variation in mean NDVI.

$\mathrm{AIC}_{c}$, Akaike information criterion corrected for small sample size; CV, coefficient of variation; NDVI, normalized difference vegetation index.

models with wetland ID as a random factor. In mixed model analysis, AICc values were computed with maximum likelihood methods for model comparison, whereas model coefficients and their $P$-values were estimated by restricted maximum likelihood methods.

Due to unusually large home range size of three beavers at Thiokol Pond Wetland (five to eight times larger than mean annual home range size of the remaining 23 beavers); separate regressions were conducted for 23 and 26 beavers, respectively. Means were reported with $\pm 1 \mathrm{SD}$. All statistical analyses were conducted at $\alpha=0.05$.

\section{Results}

Radio tracking of 26 beavers for 12 months obtained 1717 total locations. Mean 95\% kernel home range size was $20.89 \pm 26.54$ ha for 26 beavers but $11.86 \pm 5.66$ ha for 23 beavers, excluding three beavers at Thiokol Pond. Mean seasonal shift in core area was approximately $63.18 \pm 55.1 \mathrm{~m}$ for 23 beavers and $414.38 \pm 68.79 \mathrm{~m}$ for three beavers at Thiokol Pond. On average, developed areas constituted $24.61 \%$ of the three beavers but $1.72 \%$ of 23 beavers.

The best model for 23 beavers included Shannon's diversity index and total NDVI, with no competing models (Table 1). Home range sizes increased with increasing Shannon's diversity index of land covers $\left(F_{1,13}=11.66, P=0.005\right.$; Fig. 1a) and total NDVI within home ranges $\left(F_{1,13}=562.45, P<0.001\right.$; Fig. 1b). Home range sizes were also related positively to proportion of woody plant cover within home range $\left(F_{1,14}=4.25\right.$, $P=0.058, n=23$; Fig. 2 ) or the proportion of deciduous forests $\left(F_{1,14}=5.60, P=0.033\right)$. Mean percentage woody plant cover was $32.65 \% \pm 10.65 \%$ within home ranges. With all 26 radio-tagged beavers included, the best model showed that home range sizes were related inversely to temporal $\mathrm{CV}$ in NDVI $\left(F_{1,14}=4.08, P=0.063\right)$ but were related positively to 

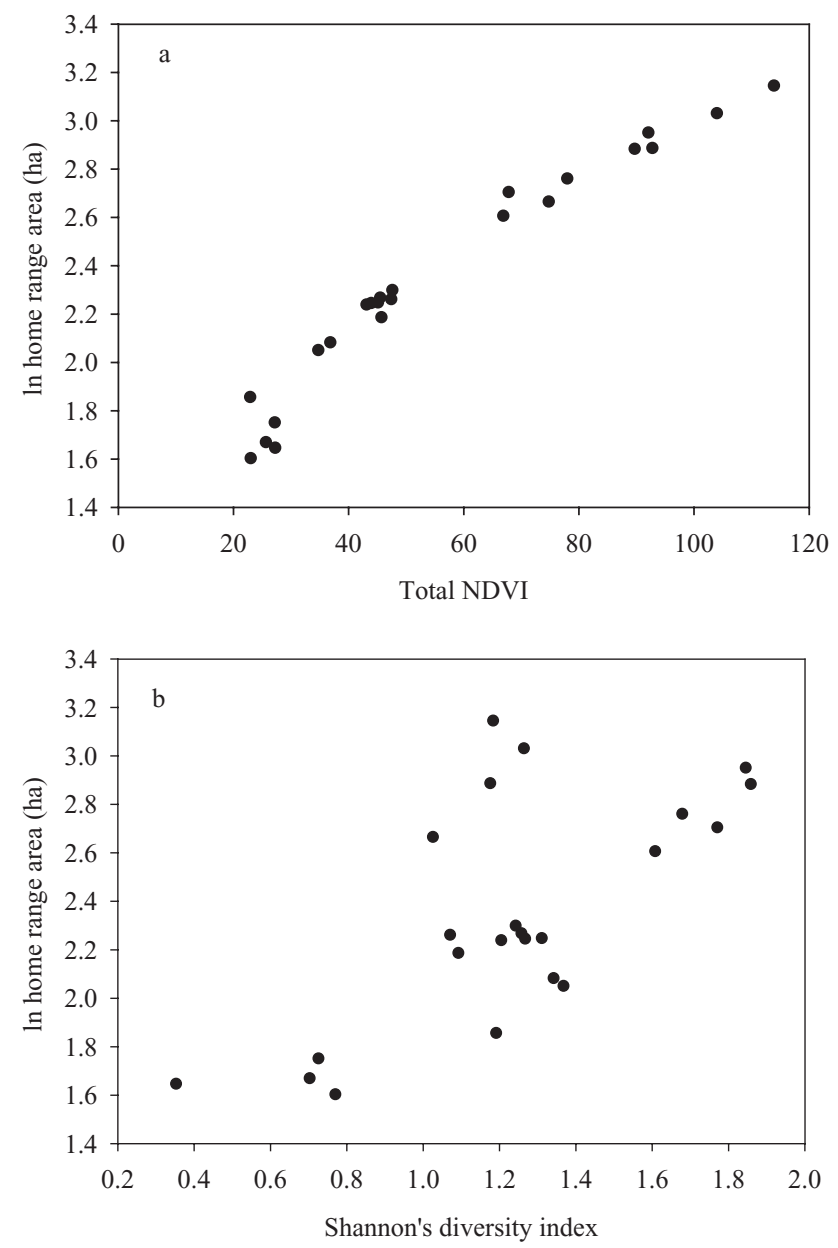

Figure 1 Relationships (a) between home range sizes and total withinhome-range normalized difference vegetation index (NDVI) and (b) between home range sizes and Shannon's diversity index of land cover of 23 American beavers Castor canadensis, excluding seasonally dispersing beavers, in northern Alabama, USA, 2011-2012.

total NDVI $\left(F_{1,14}=64.5, P<0.001\right)$. There were three other competing models within $\triangle \mathrm{AICc}$ less than 2.0 (Table 2). Additionally, two competing models included Shannon's diversity index (Table 2).

\section{Discussion}

Results on 26 beavers supported the predictions of the resource dispersion hypothesis and the temporal resource variability hypothesis, respectively (Table 1). With increased levels of habitat fragmentation, measured by land cover diversity index, beaver home range sizes increased (Fig. 1a). Beaver home range sizes decreased with increasing temporal variability in green plant material, indexed by temporal CV in NDVI. Additionally, results did not support the prediction of the habitat productivity hypothesis but supported the prediction

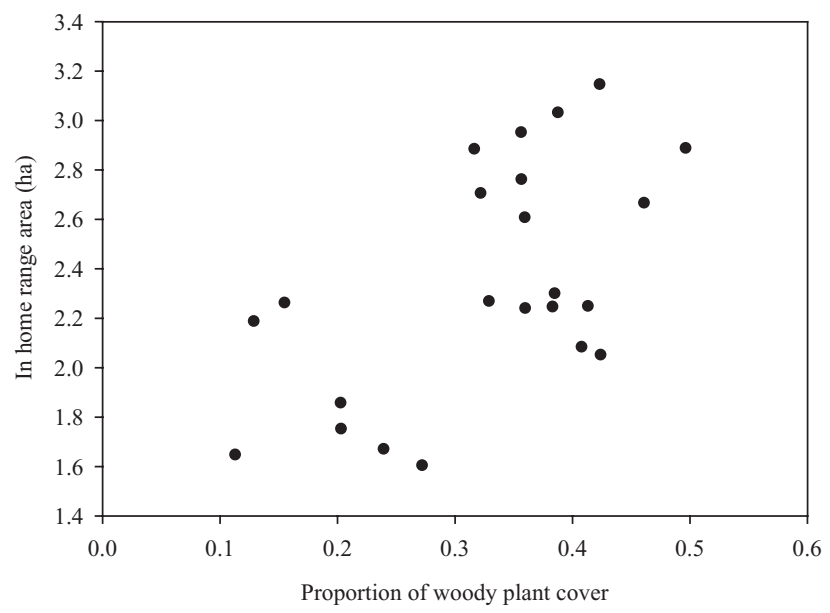

Figure 2 Relationship between home range sizes and proportions of woody plant cover within home ranges of 23 American beavers Castor canadensis in northern Alabama, USA, 2011-2012.

Table 2 Model selection of eight candidate models for 26 radio-tracked American beavers Castor canadensis in northern Alabama, USA, 2011-2012

\begin{tabular}{lccc}
\hline & & & Akaike \\
Models & $\mathrm{AIC}_{c}$ & $\Delta \mathrm{AlC}_{c}$ & weight \\
\hline Total NDVI & & \\
Total NDVI & 0.7 & 0.0 & 0.410 \\
Total NDVI + Temporal CV + Shannon's index & 2.2 & 1.5 & 0.194 \\
Total NDVI + Shannon's index & 2.6 & 1.9 & 0.159 \\
Temporal CV & 32.0 & 31.3 & 0.000 \\
Temporal CV + Shannon's index & 33.8 & 33.1 & 0.000 \\
Null & 39.5 & 38.8 & 0.000 \\
Shannon's index & 40.2 & 39.5 & 0.000 \\
\hline
\end{tabular}

Total NDVI = total normalized difference vegetation index within home range.

'Temporal CV = Coefficient of variation in mean NDVI.

'Shannon's Index = Shannon's diversity index of land cover types.

$\mathrm{AIC}_{\mathrm{c}}$, Akaike information criterion corrected for small sample size; CV, coefficient of variation; NDVI, normalized difference vegetation index.

that American beavers enlarged home ranges to increase relative amount of woody plants or include more green plant materials within home ranges (Figs. $1 \mathrm{~b}$ and 2).

Shannon diversity index of land cover used in this study represents diversity of land cover at a landscape scale, not plant diversity per unit area. More diverse vegetation types within home ranges suggested increased habitat fragmentation and probably made beavers move more between patches to gain sufficient resources, increasing home range sizes (Fig. 1a). The positive relationship between home range size and resource dispersion has been observed in mammalian carnivores (reviewed by Di Stefano et al., 2011). Our results suggest that resource dispersion may also play an important 
role in determining home range sizes of mammalian herbivores.

Model selection results provided mixed support to the temporal resource variability hypothesis. Temporal CV in NDVI was included in the best model and a competing model for 26 beavers (Table 1). Home range sizes became smaller as temporal CV in NDVI increased, with three seasonally dispersing beavers included. However, home range sizes of 23 beavers were not related to temporal CV in NDVI (Table 2). The discrepancy was possibly due to relatively small sample sizes of this study $(n=23$ and 26). Altering resource use in space and time within a home range to correspond to pulses or temporal variation in vegetation may be an effective way to increase nutritional benefits (Willems, Barton \& Hill, 2009; Searle et al., 2010). About 60-m shift of seasonal core use areas may be explained by alterations in resource use within home ranges. Roberts \& Arner (1984) observed a shift in vegetative consumption from the bark of trees in fall and winter to herbaceous vegetation in spring by beavers in Mississippi. Therefore, more temporal variation in plant production may provide beavers with different resources needed for different seasons, resulting in smaller home ranges in southeastern US with predictable seasonal variation in resource availability (Owen-Smith et al., 2010).

Our results did not support the inverse relationship between home range sizes and relative quantity of woody plants as predicted by the habitat productivity hypothesis. Woody plants produce more green biomass than herbaceous plants. The positive relationship between home range size and total NDVI (Fig. 1b) was probably because American beavers moved more to include more woody plants within home ranges (Fig. 2), resulting in larger home ranges as seen in Eurasian beavers (Campbell et al., 2005). Renewal of canopy trees damaged by American beavers' foraging takes more than 1 year. Therefore, central place foraging behavior probably drives American beavers to increase home ranges to augment the availability of wood plants for food consumption and avoid food resource depletion.

Although our results did not support the habitat productivity hypothesis at a local scale, annual home range sizes of 23 beavers averaged 11.86 ha, about half of that (25.5 ha) of beavers in southern Illinois (Bloomquist et al., 2012). The habitat productivity hypothesis predicts that beavers in the northern part of the species' range have larger home ranges than those in the southern portions of the range, because primary productivity decreases with increasing latitudes. However, the three beavers in Thiokol Pond had home ranges three to four times larger than mean annual home range of beavers in southern Illinois, and five to eight times larger than mean annual home range of the 23 beavers in this study. Mean distance between seasonal core area centroids of three beavers at Thiokol Pond was 6.56 times greater than that of the remaining 23 beavers. Furthermore, the home ranges of the three beavers in Thiokol Pond included proportionally more developed area than the 23 beavers. Therefore, habitat fragmentation by developed areas likely resulted in large home ranges. Alternatively, larger home range sizes of the three beavers in Thiokol Pond may be due to smaller social group size or greater population densities (Nolet \& Rosell, 1994). Data on the composition and size of social groups of American beavers were not collected. However, the territory size of Eurasian beavers, C. fiber, is not related to social group size (Campbell et al., 2005). Resource availability appears to be the main determinant of territory size of Eurasian beavers (Campbell et al., 2005). Although our results support the predictions of the resource dispersion hypothesis and the temporal resource variability hypothesis, observational studies like ours cannot discern the cause-effect relationship between spatiotemporal dynamics of resources and movements of American beavers. Future manipulative studies are needed to investigate relationships between social behaviors and movement patterns of American beavers.

\section{Acknowledgments}

Two anonymous reviewers and Dr. Virginia Hayssen made helpful comments on our manuscript. We would like to thank the RSA Environmental Management Division, specifically Christine Easterwood and Justin Pflueger for their logistical assistance. We also thank the funding agencies, USDA APHIS National Wildlife Research Center, Wildlife Services Alabama, Berryman Institute East, and Mississippi State University College of Forest Resources and Department of Wildlife, Fisheries and Aquaculture.

\section{References}

Arjo, W.M., Huenefeld, R.E. \& Nolte, D.L. (2007). Mountain beaver home ranges, habitat use, and population dynamics in Washington. Can. J. Zool. 85, 328-337.

Arjo, W.M., Joos, R.E., Kochanny, C.O., Harper, J.L., Nolte, D.L. \& Bergman, D.L. (2008). Assessment of transmitter models to monitor beaver Castor canadensis and C. fiber populations. Wildl. Biol. 14, 309-317.

Baker, B.W. \& Hill, E.P. (2003). Beaver (Castor canadensis). In Wild mammals of North America: biology, management, and conservation: 288-310. Feldhamer, G.A., Thompson, B.C. \& Chapman, J.A. (Eds). Baltimore: The Johns Hopkins University Press.

van Beest, F.M., Rivrud, I.M., Loe, L.E., Milner, J.M. \& Mysterud, A. (2011). What determines variation in home range size across spatiotemporal scales in a large browsing herbivore? J. Anim. Ecol. 80, 771-785.

Bloomquist, C.K. \& Nielsen, C.K. (2010). Demography of unexploited beavers in southern Illinois. J. Wildl. Manage. 74, 228-235.

Bloomquist, C.K., Nielsen, C.K. \& Shew, J.J. (2012). Spatial organization of unexploited beavers (Castor canadensis) in southern Illinois. Am. Midl. Nat. 167, 188-197.

Bond, B.T., Leopold, B.D., Burger, L.W. Jr. \& Godwin, K.D. (2001). Movements and home range dynamics of cottontail rabbits in Mississippi. J. Wildl. Manage. 65, 1004-1013. 
Breck, S.W., Wilson, K.R. \& Andersen, D.C. (2001). The demographic response of bank-dwelling beavers to flow regulation: a comparison on the Green and Yampa rivers. Can. J. Zool. 79, 1957-1964.

Buchmann, C.M., Schurr, F.M., Nathan, R. \& Jeltsch, F. (2012). Movement upscaled - the importance of individual foraging movement for community response to habitat loss. Ecography 35, 436-445.

Burnham, K.P. \& Anderson, D.R. (2002). Model selection and multi-model inference: a practical information-theoretic approach. 2nd edn. New York: Springer.

Campbell, R.D., Rosell, F., Nolet, B.A. \& Dijkstra, V.A.A. (2005). Territory and group sizes in Eurasian beavers (Castor fiber): echoes of settlement and reproduction? Behav. Ecol. Sociobiol. 58, 597-607.

Campbell, R.D., Newman, C., Macdonald, D.W. \& Rosell, F. (2013). Proximate weather patterns and spring green-up phenology effect Eurasian beaver (Castor fiber) body mass and reproductive success: the implications of climate change and topography. Glob. Change Biol. 19, 1311-1324.

Cochran, W.W. \& Lord, R.D., Jr (1963). A radio-tracking system for wild animals. J. Wildl. Manage. 27, 9-24.

Di Stefano, J., Coulson, G., Greenfield, A. \& Swan, M. (2011). Resource heterogeneity influences home range area in the swamp wallaby (Wallabia bicolor). Ecography 34, 469-479.

Downs, J.A. \& Horner, M.W. (2008). Effects of point pattern shape on home-range estimates. J. Wildl. Manage. 72, 1813-1818.

Fry, J.A., Xian, G., Suming, J., Dewitz, J.A., Homer, C.G., Limin, Y., Barnes, C.A., Herold, N.D. \& Wickham, J.D. (2011). Completion of the 2006 national land cover database for the conterminous United States. Photogramm. Eng. Remote Sens. 77, 858-864.

Fryxell, J.M. (1992). Space use by beavers in relation to resource abundance. Oikos 64, 474- 478.

Haarberg, O. \& Rosell, F. (2006). Selective foraging on woody plant species by the Eurasian beaver (Castor fiber) in Telemark, Norway. J. Zool. 270, 201-208.

John, F., Baker, S. \& Kostkan, V. (2010). Habitat selection of an expanding beaver (Castor fiber) population in central and upper Morava river basin. Eur. J. Wildl. Res. 56, 663671.

Johnson, D.D.P., Kays, R., Blackwell, P.G. \& Macdonald, D.W. (2002). Does the resource dispersion hypothesis explain group living? Trends Ecol. Evol. 17, 563-570.

Johnston, C.A. \& Naiman, R.J. (1990). Browse selection by beaver: effects on riparian forest composition. Can. J. For. Res. 20, 1036-1043.

Lauer, D.T., Morain, S.A. \& Salomonson, V.V. (1997). The Landsat program: its origins, evolution, and impacts.

Photogramm. Eng. Remote Sens. 63, 831-838.

Loveridge, A.J., Valeix, M., Davidson, Z., Murindagomo, F., Fritz, H. \& Macdonald, D.W. (2009). Changes in home range size of African lions in relation to pride size and prey biomass in a semi-arid savanna. Ecography 32, 953-962.

Marable, M.K., Belant, J.L., Godwin, D. \& Wang, G. (2012). Effects of resource dispersion and site familiarity on movements of translocated wild turkeys on fragmented landscapes. Behav. Process. 91, 119-124.

McNab, B.K. (1963). Bioenergetics and determination of home range size. Am. Nat. 97, 133-140.

McNew, L.B., Jr \& Woolf, A. (2005). Dispersal and survival of juvenile beavers (Castor canadensis) in southern Illinois. Am. Midl. Nat. 154, 217-228.

Mueller, T. \& Fagan, W.F. (2008). Search and navigation in dynamic environments - from individual behaviors to population distributions. Oikos 117, 654-664.

Nams, V.O. (2006). Locate III user's guide. Pacer Computer Software, Tatamagouche, Nova Scotia, Canada.

Nolet, B.A. \& Rosell, F. (1994). Territoriality and time budgets in beavers during sequential settlement. Can. J. Zool. 72, 1227-1237.

Owen-Smith, N., Fryxell, J.M. \& Merrill, E.H. (2010). Foraging theory upscaled: the behavioural ecology of herbivore movement. Philos. Trans. R. Soc. Lond. Ser. B. Biol. Sci. 365, 2267-2278.

Pettorelli, N. (2005). Using the satellite-derived NDVI to assess ecological responses to environmental change. Trends Ecol. Evol. 20, 503-510.

Raffel, T.R., Smith, N., Cortright, C. \& Gatz, A.J. (2009). Central place foraging by beavers (Castor canadensis) in a complex lake habitat. Am. Midl. Nat. 162, 62-73.

Roberts, T.H. \& Arner, D.H. (1984). Food habits of beaver in east-central Mississippi. J. Wildl. Manage. 48, 1414-1419.

Rothmeyer, S.W., McKinstry, M.C. \& Anderson, S.H. (2002) Tail attachment of modified ear-tag radio transmitters on beavers. Wildl. Soc. Bull. 30, 425-429.

Rouse, J.W.J., Hass, R.H., Deering, D.W., Schell, J.A. \& Harlan, J.C. (1974). Monitoring the vernal advancement and retrogradation (green wave effect) of natural vegetation. The National Aeronautics and Space Administration Greenbelt, Maryland, USA.

Searle, K., Hobbs, N. \& Jaronski, S. (2010). Asynchrony, fragmentation, and scale determine benefits of landscape heterogeneity to mobile herbivores. Oecologia 163, 815-824.

Tramer, E.J. (1969). Bird species diversity: components of Shannon's formula. Ecology 50, 927-929.

White, G.C. \& Garrott, R.A. (1990). Analysis of wildlife radiotracking data. San Diego: Academic Press.

Willems, E.P., Barton, R.A. \& Hill, R.A. (2009). Remotely sensed productivity, regional home range selection, and local range use by an omnivorous primate. Behav. Ecol. 20, 985-992.

Worton, B.J. (1989). Kernel methods for estimating the utilization distribution in home-range studies. Ecology 70, 164 168. 


\section{Supporting information}

Additional Supporting Information may be found in the online version of this article at the publisher's web-site:

Table S1. Site descriptions for 11 wetlands inhabited by American beavers equipped with radio transmitters at
Redstone Arsenal in north-central Alabama, USA, 20112012. Visually predominant vegetation types were obtained from a visual inspection of each of the 11 wetlands to help better describe individual wetland types. 
Appendix A

Table S1 Site descriptions for 11 wetlands inhabited by American beavers equipped with radio-transmitters at Redstone Arsenal in north central Alabama, USA, 2011-2012. Visually predominant vegetation types were obtained from a visual inspection of each of the 11 wetlands to help better describe individual wetland types.

\begin{tabular}{|c|c|c|c|c|}
\hline Wetland & Location & $\begin{array}{l}\text { Water Surface } \\
\text { Area (ha) }\end{array}$ & $\begin{array}{c}\text { Wetland } \\
\text { Classification }\end{array}$ & Visually Predominant Vegetation \\
\hline Blueberry & $\begin{array}{l}34^{\circ} 33^{\prime} 52^{\prime \prime} \mathrm{N} \\
86^{\circ} 40^{\prime} 14^{\prime \prime} \mathrm{W}\end{array}$ & 23.32 & Palustrine & $\begin{array}{c}\text { Alteranthera philoxeroides, } \\
\text { Cephalanthus occidentalis, Nyssa } \\
\text { sylvatica }\end{array}$ \\
\hline Corkwood Road & $\begin{array}{l}34^{\circ} 33^{\prime} 19^{\prime \prime} \mathrm{N} \\
86^{\circ} 39^{\prime} 50^{\prime \prime} \mathrm{W}\end{array}$ & 23.79 & Palustrine & $\begin{array}{l}\text { Cephalanthus occidentalis, Lemna spp, } \\
\text { Platanus occidentalis, Salix nigra }\end{array}$ \\
\hline Corkwood & $\begin{array}{l}34^{\circ} 33^{\prime} 27^{\prime \prime} \mathrm{N} \\
86^{\circ} 39^{\prime} 48^{\prime \prime} \mathrm{W}\end{array}$ & 5.68 & Palustrine & $\begin{array}{c}\text { Cephalanthus occidentalis, Nyssa } \\
\text { sylvatica, Salix nigra }\end{array}$ \\
\hline DDT Abatement & $\begin{array}{l}34^{\circ} 37^{\prime}, 28^{\prime \prime} \mathrm{N} \\
86^{\circ} 38^{\prime} 52^{\prime \prime} \mathrm{W}\end{array}$ & 29.09 & Palustrine & $\begin{array}{c}\text { Acer spp , Alteranthera philoxeroides, } \\
\text { Sparganium spp, Typha spp }\end{array}$ \\
\hline $\begin{array}{l}\text { DDT Spring } \\
\text { Branch }\end{array}$ & $\begin{array}{l}34^{\circ} 36^{\prime} 53^{\prime \prime} \mathrm{N} \\
86^{\circ} 38^{\prime} 35^{\prime \prime} \mathrm{W}\end{array}$ & 35.56 & Riverine & $\begin{array}{l}\text { Alteranthera philoxeroides, Ludwigia } \\
\text { spp, Salix nigra, Typha spp }\end{array}$ \\
\hline Hudson Park Field & $\begin{array}{l}34^{\circ} 35^{\prime} 21^{\prime \prime} \mathrm{N} \\
86^{\circ} 36^{\prime} 32^{\prime} \mathrm{W}\end{array}$ & 8.46 & Riverine & $\begin{array}{c}\text { Acer spp, Alteranthera philoxeroides, } \\
\text { Cephalanthus occidentalis, Nyssa } \\
\text { sylvatica }\end{array}$ \\
\hline Hudson Park & $\begin{array}{l}34^{\circ} 34^{\prime} 50^{\prime \prime} \mathrm{N} \\
86^{\circ} 36^{\prime} 58^{\prime \prime} \mathrm{W}\end{array}$ & 17.77 & Palustrine & $\begin{array}{c}\text { Alteranthera philoxeroides, } \\
\text { Cephalanthus occidentalis, Nyssa } \\
\text { sylvatica }\end{array}$ \\
\hline Igloo Drain & $\begin{array}{l}34^{\circ} 34^{\prime} 44^{\prime \prime} \mathrm{N} \\
86^{\circ} 39^{\prime} 20^{\prime \prime} \mathrm{W}\end{array}$ & 56.88 & Palustrine & $\begin{array}{c}\text { Cephalanthus occidentalis, Nuphar } \\
\text { luteum, Salix nigra }\end{array}$ \\
\hline Igloo Pond & $\begin{array}{l}34^{\circ} 35^{\prime} 06^{\prime \prime} \mathrm{N} \\
86^{\circ} 39^{\prime} 29^{\prime \prime} \mathrm{W}\end{array}$ & 63.74 & Palustrine & $\begin{array}{c}\text { Alteranthera philoxeroides, } \\
\text { Cephalanthus occidentalis, Salix nigra }\end{array}$ \\
\hline Patton Road & $\begin{array}{l}34^{\circ} 38^{\prime} 02^{\prime \prime} \mathrm{N} \\
86^{\circ} 37^{\prime} 51^{\prime} \mathrm{W}\end{array}$ & 7.46 & Palustrine/Riverine & $\begin{array}{c}\text { Alteranthera philoxeroides, Equisetum } \\
\text { spp, Salix nigra }\end{array}$ \\
\hline Thiokol Pond & $\begin{array}{l}34^{\circ} 37^{\prime} 20^{\prime \prime} \mathrm{N} \\
86^{\circ} 35^{\prime} 40^{\prime \prime} \mathrm{W}\end{array}$ & 46.36 & Palustrine & $\begin{array}{c}\text { Alteranthera philoxeroides, Ludwigia } \\
\text { spp, Nyssa sylvatica, Quercus spp }\end{array}$ \\
\hline
\end{tabular}

